\title{
Ousmane Sembène's Les Bouts de bois de Dieu: The Mechanics of Change
}

Fawzia Ahmad-Slavin

Boston University

hange is implicit in Ousmane Sembène's Les Bouts de bois de Dieu: change of political order imposed by the ruling power of the European colonizers as well as change of social order. Against the background inspired by the five-month strike of the Dakar-Bamako railway workers during 1947-48, Sembene creates specific situations that transform his characters' lives. The several characters of the author's constructed reality are faced with (at different instances) the question of progress, of whether or not to leave behind their traditions in hopes of a new order of things. An acclamation of efforts of progress of the laborers who referred to themselves as 'God's bits of wood,' Les Bouts is a creation which renders even the most simple social structure in the workers' lives as part of the larger revolution which was sweeping through the strikers' communities. This paper is a reading of the dialectics of the individual metamorphosis when confronted with a collective transformation as a group.

Throughout the novel, Sembene's cinematic prose gives the reader numerous exposures of this progress. The circumstances as provided by the strike in the novel raise questions first individually and then collectively about preconceived notions of race, class, and traditional customs for the characters - questions that Sembene has posed himself and places the answer in the strikers' leader's words: «L'homme que nous étions est mort et notre seul salut pour une nouvelle vie est dans la machine, la machine qui, elle, $n^{\prime}$ a ni langage ni race.» ${ }^{1}$ The machine's structure is the starting point for our analysis of change in woman's and man's struggle for independence from oppression from her/his own preestablished criterion and that of the dominant culture surrounding her/him.

When the strikers look upon a distant locomotive with aspiration, their hearts swell with communion with the machine and what it represents. The structure of a performing/working entity as the machine not only helps break down the barriers which separate the workers from human progress, but it is also the arena where race, and class 
differences are neutralized. By presenting technology as the 'savior' for the oppressed laborers, Sembene constructs a new mythology of progressive change in his novel. The machine and the technology that it represents becomes a prototype of Sembene's progressive ideology which leads to transformation from tradition. The railway workers livelihood and fortitude must come from the locomotive's technology which is oblivious to the color of their skins and their status as employees. It can no longer remain the domain of the ruling minority as it is a tool for all. In this way, Sembene portrays technology as a force with which to grapple, a force that must be reappropriated as the workers path to change.

By locating the structure of change in an inanimate entity, Sembene transcends the all-too-familiar critique of the colonial power and concentrates on the specific transformations which are linked to individual responses to the 'global' or bigger change. On the one hand, this parallels Fredric Jameson's assertion that all individual acts are ultimately political in nature as in the following statement: "... [T]here is nothing that is not social and historical - indeed, ... everything is "in the last analysis" political ${ }^{2} \mathrm{On}$ the other hand, Sembene's text cannot be viewed exclusively as a ways or means to a larger cause. Les Bouts is rather an affirmation of the very difference in individual responses to change - even if the changes ultimately lead to a 'bigger' common cause. Sembene's narrative selects these differences for the reader and presents them in all their specificity without the metacommentary of an oppressed laborer raising his/her head from under a dominant colonizer's rule. Sembene's main concerns lie ultimately in touching and thus bringing out the varied range or reponses of his characters when faced with "rethinking everything."

The mechanics of change are thus given just as much importance in Sembène's Les Bouts as the end result of this change. As the inner workings of a machine are vital to the function that it must perform, the created inner changes in the strikers' communal groups are reflective of, and eventually lead to the bigger revolution taking place around them. In our reading, we will demonstrate that individual action must then be viewed as part of the process of change on the whole. In their study, Kafka, pour une litterrature mineure, Gilles Deleuze and Felix Guattari have effectively called this as one of the characteristics of minor litterature: «... le branchement de l'individuel sur l'immédiat-politique.»

When we locate the individual, social, and political implications of the strike in Les Bouts, we can trace a horizontal movement, or what Eileen Julien refers to as a 'democratic' element ${ }^{4}$ in the change portrayed in the novel. And, in as much as the change in women's position is created in Les Bouts, Sembène's female characters exemplify this connection of change from its humble beginnings to the political reality of their accumulated changes. Indeed, our reading of the gradual transformation of the women's every-day lives and the dynamics of their intervention in the accepted codes of ordinary events will reveal Sembene's attempt to show the brewing of a struggle on the larger scale in minor happenings. The previous notions of home, family, and sexuality are challenged by the actions of these women. By locating the nucleus of 
change in the female characters of Les Bouts, our focus in this paper exposes the workings of such change. In choosing the female characters, we will not only try to demonstrate the break from dependency on old ways that Sembene's ideology exemplifies in this novel, but also explore the trajectory of change as brought out by the womens' individual reactions to their given conditions. From the 'micropolitics' 5 of such challenges, Sembene portrays the universality of the winds of change that sweep his novel's domain.

Not surprisingly, the author's predetermined opening setting in the novel coincides with the women's pre-change state. The men's meetings regarding the strike are already under way. But as readers, we are led first to the women's gathering where the change has yet to take place: «Rien que des femmes. Tout en s'affairant à leurs travaux ménagers, elles jacasaient, chacune parfaitement indifférente à ce que disait l'autre.» (13-14). Their roles about to be transformed, the women in Sembene's narrative are singled out to take on new directions towards a collective end. In other words, the women exemplify the difference between what Aijaz Ahmad refers to as "... those who make history and those who are mere objects of it."

When Sembene acknowledges as an author and a cinematographer: "How do I best communicate with my people and my era? That's what I worry about," he is making way in his novels and films to "... constantly create our own models. ${ }^{\prime 7}$ We will see that in Les Bouts, each character is a self-created model for herself. What Sembene has said about his films is equally true of the mobilization of the women's change as a result of their new situation in Les Bouts:

I want to be understood at different cultural levels. I select my subjects with social and political implications. I detail and narrate my stories in my own way. I speak to the house wife just as I speak to the philosophy professor. If I am not understood by the masses, I will consider myself a failure.

Let us explore in detail the evolution of independence, the transcendence of some female characters from the old, local and self-sufficient seclusion that Sembène's traces in his novel.

\section{In the company of women}

With a deft eye not unlike a camera's lens, Sembène opens his 'scene' in the company of women as if to prefigure a revolution within a revolution that will take place for some female characters in the novel. Leading his reader's eye to the heart of change - in the women's homes, Sembene focuses on the hearth to project the old versus the new order of things. The transformation will come from within and the reader is already made sensitive to this. In this opening scene, then, the men are absent since they are away at strike. The women, left to their affairs, chat about mundane affairs. Keeping this idle sedentary existence in mind, the reader may then compare this first image to the 
evolution in each female character as Sembène portrays the gaining momentum of the trajectory of change.

A movement from the single (here the small unit of women) to the multiple will ensue as the effects of the strike reach the women, they first react to it individually and then collectively as when they join forces to march to Dakar. In choosing the women's gathering at Bamako as his first opening 'scene,' Sembène practices what Françoise Pfaff effectively names "selected reality" in her discussion of Sembene as film-maker in The Cinema of Ousmane Sembene, (46). The women are not relegated to the margin as is evident by the selection of a women's group in this beginning scene. The universality of the strike effects all and not just the pre-dominantly male group that has organized the strike.

Sembene focuses readily on the old Niakoro and the young Ad'jibid' $\mathrm{ji}$, two poles that represent the past and the present of the women's lot. The contrast is clear: «... que representait Niakoro-la vieille pour ces femmes occupées de la seule heure présente? A peine le souvenir d'un passé révolu qui s'effaçait lentement.» (16). While the old Niakoro remembers her past, Ad'jibid'ji frolics with abundant energy of the present. Sembene rarely offers a personality analysis of his characters in this novel but, nevertheless, lets the reader know where his sympathies lie when he favorably describes the young girl: «Adjibid'ji n'était ni irrespectueuse, ni effrontée. Au contraire sa maturité, sa spontanéité, sa lucidité stupéfiaient tout le monde et d'abord Niakoro elle-même.» (19). Sembene chooses a little girl as the first representative of his preferred ideology of progressive change as she represents modernity and evolution. So, it is not in the ideological harangue of the men's meeting that the reader first encounters change for the better but in the spirit of a little girl. Ad'jibid'ji crosses the frontier that separates the old from the new as she sets out to join the men's meeting. When reminded of her 'place' by the old Niakoro, Adjibid'ji simply replies «... j'apprends» as an explanation of her departure.

Indeed, learning plays a prominent role in the novel in which the strike becomes the common learning ground for new lives for both women and men. Learning replaces the old ways that hinder the progress for the characters in Les Bouts. Whether it is learning the European language or new technology, it represents a breaking away (and not without a certain pain) from stagnant norms that dwell on their myopic views. The contrast between the old and the new is nowhere more apparent than the old Niakoro's admonition cited below and the young Ad'jibid'ji's self reliance which Sembene effectively makes his young character demonstrate in the only way a child of eight or nine years could-in her direct reply:

- Tu n'as jamais vu une grève, toi! Ton petit père en vu une lui, et il était encore jeune. Des soldats vont venir. Is tireront. Et toi, au milieu des hommes, tu seras comme une chève au milieu de chameaux en débandade. Tu n'as donc pas peur? 
- De quoi, mama?

- Tu demandes de quoi? Mais qu'est-ce que tu as dans la tâte?

- Du cerveau, mama, rien que du cerveau, répliqua Ad'jibid'ji en se balançant d'un pied sur l'autre, les mains derrière le dos, tandis que sa camisole de cotonnade trop grande pour elle flottait autour de son corps frêle (19).

Ad'jibid'ji has already learned the meaning of independence and to arrive at that stage she has had to learn more than a few verses of the Koran - the extent of her grand-mother's learning. Sembene thus sets the stage of transition from the traditional to a new way of learning and accepting change - a confidence in the capacity of the self.

As the case of Ad'jibid'ji shows, learning for women has, no doubt, a double effect on their status in Les Bouts. First, it is the breaking away from the traditions of the previous generation and in doing so, incurring the latter's wrath - Niakoro calls them "déracines," and secondly, knowledge and learning enable them to cross the male/female boundaries that were previously established. As the young Ad'jibid'ji leaves behind the women's gathering to attend the men's meeting, her action prefigures the transition to come in the womens' lives as they confront new challenges.

\section{New men, new women}

Sembène does not stray too far from the women's world on which he first focused when he retains the first few stirrings of change amongst the women virtually close to home. The lack of food brings the women together and the awareness of this direct effect of the strike assembles the women to begin making their rounds for food within their neighborhoods. When the repercussions of the strike reach the children who are faced with hunger, Sembene exposes a deliberate series of cause and effects that portray the gathering of force of the women's movement:

... [les enfants] étaient là, errant dans les cours ou accrochés aux pagnes avec leurs os qui saillaint, leurs yeux creux et toujours cette question qui vous broyait le cœur: «Mère, est-ce qu' on va manger aujourd'hui?» Alors, on se réunissait, à quatre, à dix, les bébés accrochés au dos. La marmaille suivant ou précédent: on disait: «Allons chez Une Telle, peut-être qu'elle a encore un peu de mil» et l'errance commençait, de demeure en demeure. Souvent Une Telle disait «Eh, jen'ai plus rien, je vais avec vous»: elle prenait un bébé sur son sein flasque et $s$ 'en venait augmenter le cortège. Parfois on arrivait chez une qui avait de l'eau: elle tenait une calebasse à la ronde, mais elle disait «Ne buvez pas tout!» $(64-65)$.

Alors in the above passage is Sembene's matter-of-fact reasoning for the consequent relay effect of the women's force. As each one, «Une Telle,» goes from door to door and 
is joined by more and more women, a momentum is built up in Sembène's text: «... et l'errance commençait ... elle prenait un bébé sur son sein flasque et s'en venait augmenter le cortège....» (65)

From these small awakenings to their present condition, Sembene singles out one particular case: «Un matin, une ferme se leva, elle serra fortement son pagne autour de sa taille et dit: - Aujourd'hui, je vous apporterai à manger» (65, emphasis added). The resolute action of enveloping the pagne tightly around the waist equals the decision of taking charge of one's situation. The transformation from idle chatter to action, from object of circumstances to subject of action is assigned to an anonymous character, hence «une femme.» As this unnamed woman enters into the arena of action, she forgoes her role of spectator and acquires that of the doer. A new woman is thus born: «Et les hommes comprirent que ce temps, s'il enfantait d'autres hommes, enfantait aussi d'autres femmes.» (65).

The fact that Sembene does not assign this symbolic gesture to one of his main female characters reveals that the change is inherent to the situation of these women. The first stirrings of change are thus given importance. Sembene's scenario casts women who have not yet participated in action but have so far been mere bystanders. Their individual responses to the crises around them will have a mobilizing effect on their actions in Les Bouts. The obvious needs to be pointed out here to support our observation that change is generic to these women: these are not heroines of mythical qualities, goddesses of superhuman strength but instead common house-wives, mothers like so many around them, who must deal with their ordinary but pressing material concerns. By bringing change into their very quotidian existence, the women in Les Bouts uphold Sembène's philosophy of social change to topple colonial oppression. Each protest, no matter how trivial, against unjust power carries the germ of a larger revolution. For example, when Mame Sofi acquires water for her thirsty children and other women in similar situation, she must contend with the water carrier's demands of payment. Not having money on hand, she promises to repay the man. When the latter threatens her, she repudiates his insults by a daring slap on his face - an act she would not have attempted under ordinary circumstances. Sembene has made it clear in his novel that these are no ordinary circumstances for all involved. Wole Soyinka has aptly described this new order in Sembene's novel as "The social community (which) acquires archetypal dimensions...."9

\section{Ramatoulaye's reoolt}

In a pivotal episode in the women's awareness, a simple woman, Ramatoulaye, kills her brother's ram. What at first seems a fit of rage against the poor beast, the text later reveals that this action was dictated by a sense of 'duty': «Il n'y avait dans son regard ni fierté ni orgueil, simplement une sorte de satisfaction comme si son acte n'avait été qu'un devoir dicté par la fatalité.» (115). The potential for change then is present in the force and courage of a response to a situation (in this case, hunger). Ramatoulaye, 
oppressed by her hunger and that of others around her, revolts against her situation. She takes charge of the events around her to act on her surroundings. As she breaks from tradition in not only ignoring her dress while in struggle with the animal (kon ne meurt pas d'être nu!» [115]), but also in demonstrating 'violence' by killing the ram, Ramatoulaye is effective in shrugging off prescribed roles for women. Furthermore, she views her action in all its logical reasoning implying that she would do the same if similar circumstances were to arise again:

Ce matin, j'avais dit à mon frère Mambigué que je tuerais Vendredi. Dieu m'est témoin que ce n'est pas à cause de cela que je l'ai fait. C'est parce que nous avons faim, trop faim. Les hommes le savent bien, mais eux, ils partent tôt le matin et ne rentrent que le soir venu (117).

In Ramatoulaye's character, Sembene demonstrates that lucidity and the ensuing deliberate action are the very dynamics of change in women in her situation. More attuned than the men to the problem of hunger around her by her mere presence of body and mind, Ramatoulaye is pushed by the necessity of the moment to kill the ram for meat. Realizing that there would be nothing but her own strength to rely on, she is thus driven to action. This parallels what Trinh Minh-ha writes in Women, Native, Other: "... such a responsibility (of action) does not exclusively devolve upon women, but it is women who are in a better position to accept it." (102). Like Sembene, Minh-ha has pointed out that there can be no social-political revolution without a r-eoolution of subjects. Indeed, Sembène's creation of Ramatoulaye's action in response to her evaluation of needs around her posits her in a better position to act by taking matters in her own hands rather than leaving them to others.

Moreover, Ramatoulaye's assertive act oversteps the traditional codes of behavior set for women in her community. Brut force and self-abandon in pursuit of the hapless animal are perhaps unlikely displays of a woman's public behavior in her community. But, Ramatoulaye's aggression has a heroic outcome in Les Bouts for she manages to feed the essential meat to the members of her compound. In her realization that: «La Providence est grande, mais chacun doit prendre sa part.» (116), she forgoes the gender differences that if upheld would have prevented her from killing the ram. When asked why she involved herself in such a mêlée, Ramatoulaye upholds a commitment to the self the part she has assigned to it. She replies:

Je savais que Dieu était de mon côté, dit Ramatoulaye. Je sais aussi qu'on peut mourir de faim, et je sais encore que Houdia M'Baye n'a plus de lait! Dieu sait tout cela, lui aussi... (116-117).

The emancipation of Ramatoulaye's position then comes from a r-eraluation of her self in her surroundings which lead to the r-evolution to which Minh-ha refers. As a subject of her own action, Sembene's female 'heroine' chooses to act upon her deterio- 
rating situation rather than wait for help either from the men or even from religon. As the ram is owned by her brother who parades his false devotion to Islam (the animal will probably be used for sacrifice to celebrate a religious festival), it becomes a dual symbol of the patriarchal, religious oriented society in which Ramatoulaye must assert herself. Thus, when she kills the ram, she destroys the two myths of male-domination and the self-complacency of religious beliefs that pose as obstacles to this self-assertion.

Carolyn Heillbrun's discussion of female identities in Reinventing Womanhood identifies women at the peripheral stage as the outsiders in ways unique to them. But the very movement from the periphery to the center is relevant to the remaking of Ramatoulaye's new identity in the novel. Once Ramatoulaye enters the center stage of the ram episode, she no longer remains the outsider to aggression. Taking charge of a situation and even heroism in her own right, she takes on the central role of her action. In this manner Sembene's Ramatoulaye revises heroism. Bravery is not contingent upon race or gender. Heroic acts are rather propelled by the immediacy of the situation. Instead of a grandiose explanation of Ramatoulaye's character and what her action symbolizes, Sembene grounds her heroism in her reality. So as not to leave any doubt about the inspiration for the feat in Ramatoulaye and the other women she represents, Sembene provides this answer in his text:

D'où lui était donc venue cette force neuve, où était la source de cette force qui se déchaînait soudain? Ce n' était pas à la guerre, Ramatoulaye n'était pas un homme, $n$ 'avait pas été soldat, elle n'avait pas connu les longues marches sac au dos au cours desquelles on amasse les rancœurs. Ce n'était pas à l'usine, Ramatoulaye n'avait jamais été soumise aux inhumaines cadences du travail ouvrier. Ce n'était pas dans de multiples étreintes d'hommes. Ramatoulaye n'était pas de celles qui dilapident leur tendresse. Où donc alors? La réponse était simple comme elle l'était elle-même: dans les cuisines aux foyers éteints (124).

\section{«Nous partons, nous partons, partons, partons ...»}

The women's march crowns the change which has developed throughout Les Bouts. The force of the spirit that assembles this march from Thies to Dakar surprises the men and even some women themselves. Just as Ramatoulaye had killed the ram to feed all those who were hungry, Penda takes charge of the situation and acts:

- Je parle au nom de toutes les femmes, mais je ne suis que leur porte-parole. Pour nous cette grève, c'est la possibilité d'une vie meilleure. Hier nous riions ensemble, aujourd'hui nous pleurons avec nos enfants devant nos marmites où rien ne bouillonne. Nous nous devons de garder la tête haute et ne pas céder. Et demain nous allons marcher jusqu'à N'Dakarou.

Un murmure d'étonnement, de curiosité, de réprobation cou- 
vrit un instant la voix de Penda, mais elle reprit plus fort:

-Oui, nous irons jusqu'à N'Dakarou entendre ce queles toubabs ont à dire, et ils verront si nous sommes des concubines! Hommes, laissez vos épouses venir avec nous! Seules resteront a la maison celles qui sont enceintes ou qui allaitent et les vieilles femmes (288-289).

With a prostitute and a blind mother as their leaders, the women venture into their march. By proclaiming themselves leaders of the women's march, they remake their identities with their actions. The strike presents itself as an occasion to the women to express themselves. And by doing so, they transform themselves. Former representatives of 'marginalized' members of their community, Penda and Maïmouna thus enter into the main arena. The reader discovers that this is not an easy role: faced with physical hardship, strife and even demoralization, the women and their followers struggle to keep walking as a unit and thus create their own identity as women. This walk apparently in support of the 'men's' strike becomes the women's own walk for their identity : «Nous avons aussi gagné la grève.» (312).

Once again the women have proven to themselves that it is in their action and not inaction, in acknowledgement of their own power that they can realize their being's potential. The women's walk does not materialize from a need to prove one thing or the other to their men but rather to themselves. This is why when their identity is threatened, as in the white colonizers label of 'concubines,' they act.

\section{A case for Penda}

Penda's promiscuous yet non-hypocritical lifestyle is the antithesis of a pious moral leader of the women's march. If the worker's strike in Sembene's novel has been described as the democratization of an epic, or as Julien states in African Nooels and the Question of Orality, "... it is a revision of epic, which shifts the emphasis from birth, destiny, and oracles," (68), then the choice of the women's leader, Penda is the dismantling of the traditional (and so, moral) leader of her gender.

Once again, Sembène affirms that it is in his characters' actions that lies their value or their downfall and not in the preconceived notions of their being. Penda gives refuge to the blind Maïmouna, is enraged by false pretenses of both men and women and breaks away from established norms in more ways than one when she gathers women in her call for the march: «- Nous partons, nous partons!» (292).

\section{Change and difference}

Sembene's mechanics of change is a series of contrasts of the old and the new as we have discussed in the cases of Niakoro and Ad'jibid'ji, El Hadji Mabigue and Ramatoulaye. Furthermore, the development in women's standing is separate from the men's demands of the strike even though their goals remain similar: reclaiming rights for the 
workers of the railroad. The difference between men and women in Les Bouts, then, lies in their individual actions. Faced with their immediate problems of hunger, health and their children, the women learn to satisfy their needs. They procure food when needed and support each other when in need, all with the awareness of their plight as in Ramatoulaye's confession: «Ah! nous vivons des instants cruels, nous sommes obligés de nous forger une dureté, de nous raidir. Plus ça va, plus les temps deviennent durs.» (117). While it is depicted as if it is their lot to do so as in Dieynaba's remark: «C'est toujours comme ça quand on a besoin des hommes, ils ne sont pas a la maison.» (57), she does proceed to wash the blind Maïmouna's wounds herself. In an "organic revolution" as Wole Soyinka describes this one (120), the women make do with what they have.

Thanks to the strike, hunger, hard times have certainly struck the women's lot. This effect of the strike, however, gives the women in Les Bouts a chance to express themselves and enter new paths. The strike then becomes a true learning ground for all those who are effected by opening new avenues for them. The old Niakora, lamenting the judgement against an old member of their community, reluctantly steps into the court room set up by the workers. Sembene is quick to contrast the old woman's initiative, however hesitant it may be, with Ad'jibid'ji's frisk entrance and acceptance of a new domain and thus gives the women's entrance to new paths a literal rendering: «Déja, de son pas léger, Ad'jibid'ji en grimpait les marches deux à deux...» (emphases added, 145).

On the other hand, the men have had to accomodate the new presence of women in their court decisions and public speeches. While they are not exposed to the daily tribulations of their family needs as are the women, their concerns revolve around the challenges their demands as strikers pose their old ways of living. Setting a trial and taking responsibility for their decisions offer new challanges to them as this was previously done for them by their colonial employers. Tiemoko must remain steadfast on his decision on the judgement of a fellow community member:

Tout en marchant, il mettait son plan au point tandis qu'une puissante exaltation s'emparait de lui. Pour la première fois de sa vie, une idée de lui allait mettre en jeu le destin de centaines de milliers d'êtres humains. Ce n'était pas l'orgueil qui était en lui simplement, il venait de découvrir sa valeur d'homme (147).

Faced with changes that education can bring them, the men must deal with new concepts. Tiémoko discovers this in his own voice: «... je m'instruisais, sais-tu qu'après cette grève, il faudra que nous organisions des cours. Et puis ce livre est compliqué et je ne suis pas trop d'accord avec son auteur.» (148). Others' voices also challenge the norm of the colonial employer as authority as the strikers learn to restate their positions vis-à-vis their oppressors: «Monsieur le directeur, vous ne représentez ici ni une nation, ni une race: une classe. Et nous aussi nous représentons une classe dont les interêts sont différents de ceux de la vôtre» (281). 
As each one is touched by the strike's presence, the multitude of the strike's effects on different individuals leads to a new, if not sometimes heterogenous effect on the workers. Bakayoko, the leader, is not immune to the sometimes confusing effects that the strike's changes have on the men in Les Bouts and his relative aloofness has been much discussed. ${ }^{10}$ Sembene does not privilege his leadership but exposes it with its strengths as well as weaknesses as he does for the rest of his characters. As Bakayoko leads the way to the future, the strike effects him individually as well. Sembene does not portray him as a deity independent of mundane weaknesses: «Bakayoko avait-il eu quelques remords de ses infidélités? Nul n'aurait pu le savoir tant étaient secrètes les pensées de cet homme. Peut-être le spectacle de la détresse morale autant que matérielle qu'il avait eu sous les yeux au cours de ses tournées pendant toute la durée de la grève l'avait-il mûri?» (365).

The difference of reactions to events related to the strike in Les Bouts have been brought out not to put them on a balance to weigh each 'side's' worth or impact but rather to create a setting for Sembene's purpose in this regard in his novel: to construct the broadest and the most democratic impact of the changes brought on by the strike on the men and women of his novel. To continue the cinematic comparison in Les Bouts, we could view this position as one of a wide-angle lens.

We have seen how Sembene's female characters break away from the boundaries of home when they face changes. They break away also from the gender and class limits that they eventually reconstruct with their new identities. As women acknowledge their own identities and follow through with their actions on their determination, they evolve into subjects rather than remain objects of their circumstances. From Ad'jibid'ji's maturity to Ramatoulaye's force to Penda's courage, the women are, to borrow Julia Kristeva's terms, subject(s)-in-the-making in Les Bouts. Ramatoulaye and Penda and other women they represent, are self-made leaders. So are the men.

That the strike as a vehicle of change is in itself a relative phenomenon is illustrated by the varied reactions of Sembene's numerous characters. The strike is certainly not exclusive to the men's domain for the author has shown how it effects all concerned the women, the children. The strike seeks its own modus operandi from even such simple surroundings as the cold hearth of a home. It is then not just one centralized movement but a universal effort of different proportions. Indeed, Sembene portrays the strike in all its manifestations, in its widest scope when he places the inspiration for revolt in a humble but courageous woman's cold hearth. By creating minor changes in women's lives as they struggle to survive the effects of the strike, Sembene manages to penetrate into the most humble manifestations of revolution that his female characters' actions demonstrate. It is Sembene's intent that it is only upon viewing them from such close range that we may as readers understand the larger change of which they are germs. 


\section{NOTES}

'Ousmane Sembène, Les Bouts de bois de Dieu (Paris: Presses Pocket, 1960), p. 127. All subsequent quotes are taken from this text.

${ }^{2}$ Fredric Jameson, The Political Unconscious, Narrative as a Socially Symbolic Act (New York: Cornell University Press, 1981), p. 20.

3Sembene's remark to Gary Dauphin in "Into Africa," Voice, September 18, 1990.

"See Eileen Julien, "The Democratization of Epic: Les Bouts de bois de Dieu," African Nooel and the Question of Orality (Bloomington: Indiana University Press, 1992).

${ }^{5}$ We are indebted to Carolyn G. Heilbrun's Reinventing Womenhood for her use of 'micropolitics' in feminist discourse.

${ }^{6}$ Aijaz Ahmad, "Jameson's Rhetoric of Otherness and the "National Allegory," Social Text, 17 (Spring '87), p. 7.

7Dauphin, "Into Africa."

${ }^{8}$ K.L. Arora, "Africa Speaks Out," Film World, 16 (March 1979), pp. 67-69.

'Wole Soyinka, Myth Literature, and the African World (Cambridge: Cambridge University Press, 1976), p. 117.

10We do not believe that Bakayoko's absence "accords him his extraordinary power over both the other strikers and the reader" as Eileen Julien states in African Novels and the Question of Orality. Rather, Bakayoko's aloofness is indicative of Sembene's, to use Julien's own term, 'democratization' of the epic hero. 


\section{WORKS CITED}

Ahmad, Aijaz. "Jameson's Rhetoric of Otherness and the National Allegory." Social Text, 17, Spring, 1987.

Aurore, K.L. "Africa Speaks Out." Film World. Vol. 16, n. 3, March, 1979.

Dauphin, Gary. "Into Africa." Voice. September 18, 1990.

Deleuze, Gilles, and Felix Guattari. Kafka, pour une littérature mineur. Les Editions de Minuit, 1975.

Gauthier, Xavière. "Oscillation between Power and Denial." Interview with Julia Kristeva. New French Feminism.

Heilbrun, Carolyn, G. Reinventing Womanhood. W.W. Norton \& Co., New York, 1979.

Jameson, Fredric. The Political Unconscious, Narratioe as a Socially Symbolic Act. Cornell University Press, 1981.

Julien, Eileen. African Novels and the Question of Orality. Indiana University Press, 1991.

Minh-ha, Trinh. Woman, Native, Other. Indiana University Press, 1989.

Françoise Pfaff. Twenty-five Black African Film-makers. Greenwood Press, 1988. . The Cinema of Ousmane Sembene. Greenwood Press, 1984.

Sembène, Ousmane. Les Bouts de bois de Dieu. Le Livre contemporain, 1960.

Soyinka, Wole. Myth, Literature, and the African World. Cambridge University Press, 1976.

Secondary Sources

Lévi-Strauss, Claude. Race et Histoire. Editions Gonthier, 1961. . Structural Anthropology. Basic Books, 1963.

Mohanty, Chandra, Ann Russo, Lourdes Torred, eds. Third World Women and the Politics of Feminism. Indiana University Press, 1991. 